Sylwia Stryjkowska

(Uniwersytet im. Adama Mickiewicza w Poznaniu)

mgr, sylwia.stryjkowska@amu.edu.pl

ORDCID iD: 0000-0003-0404-4935

\title{
Wpływ II wojny światowej na poszukiwanie rozwiązań prawnych w zakresie ochrony dóbr kultury
}

Wybuch II wojny światowej we wrześniu 1939 r. zastał społeczność międzynarodową nieuzbrojoną $\mathrm{w}$ efektywne narzędzia prawnej ochrony dóbr kultury w czasie konfliktu zbrojnego. Ograniczeniu skali strat pomóc miały spontaniczne próby organizowania ochrony ad hoc, poczynione już na początku konfliktu. 4 września 1939 r. Międzynarodowy Urząd Muzeów wystosował do wszystkich państw walczących komunikat z propozycją zastosowania szeregu środków ochronnych. Przygotował nawet projekt deklaracji nawołującej do współpracy w służbie dóbr kultury, która we wstępie stanowiła, że "strata dzieła sztuki jest zubożeniem duchowym nie tylko narodu, który je posiadał, ale także całej społeczności międzynarodowej"1. Mimo słusznych założeń, Deklaracja nie miała szans powodzenia - podpisały ją tylko dwa państwa: Belgia i Holandia.

Jeszcze wcześniej, bo już 1 września 1939 r. prezydent Roosevelt wystosował do stron wojujących apel, w którym postulował zakaz bombardowania ludności cywilnej i miast nieufortyfikowanych ${ }^{2}$. Wszystkie rządy, nie wyłączając rządu hitlerowskich Niemiec, odniosły się pozytywnie do posłania prezydenta. Hitler oświadczył nawet, że sformułowane przez Roosevelta postulaty „odpowiadają absolutnie" jego własnym poglądom i zapewniał o wydanym rozkazie ograniczenia przez niemieckie lotnictwo działań wojennych do obiektów wojskowych ${ }^{3}$. Wyrazem poparcia dla potrzeby ochrony dzie-

${ }^{1}$ D. Drewniacki, Międzynarodowa ochrona dóbr kultury w razie konfliktów zbrojnych. Materiaty $i$ komentarze, Warszawa 2000, s. 43.

2 J. Świeczyński, Grabieżcy kultury i fałszerze sztuki, Warszawa 1986, s. 68.

${ }^{3}$ D. Drewniacki, dz. cyt., s. 44. 
dzictwa kulturowego miał być również swoisty "dekalog”, zamieszczany w książeczkach żołnierzy Wehrmachtu, w którym znajdowały się m.in. takie przykazania: „1. Walcząc o zwycięstwo, żołnierz niemiecki będzie przestrzegał zasad rycerskości. Okrucieństwo i bezprzedmiotowe niszczenie są poniżej jego poziomu. 2. Ludność cywilna jest święta. Grabienie i rozmyślne niszczenie nie są żołnierzowi dozwolone. Zabytki o znaczeniu historycznym oraz budynki służące celom religijnym, sztuce, nauce i dobroczynności należy otaczać szczególną opieką"4.

Praktyka wyglądała jednak zupełnie inaczej. Planowość, zamysł, systematyczność i totalność stanowiły naczelne cechy niszczycielskiej polityki Niemiec ${ }^{5}$. Żaden z wcześniejszych konfliktów zbrojnych nie przyczynił się do takich strat w zakresie dóbr kultury jak II wojna światowa ${ }^{6}$. Ich zniszczenie było w przeważającej mierze wynikiem bombardowań lotniczych, w których niejednokrotnie niemalże równano z ziemią całe miasta. Nie można zapominać, że piętno na kulturowych zasobach podbitych narodów odcisnęły także przeprowadzane na ogromną skalę grabieże, wspomagające gospodarczy rozwój Rzeszy. Odznaczały się one przy tym znacznym stopniem zorganizowania konfiskaty przeprowadzał powołany $\mathrm{w}$ tym celu urząd specjalnego pełnomocnika do spraw rejestracji i zabezpieczania dzieł sztuki i zabytków kultury na terytoriach okupowanych ${ }^{7}$, a poszukiwania cennych dla Niemiec dóbr kultury prowadził Sztab Operacyjny Rosenberga (EinsatzstabReichsleiter Rosenberg) - organizacja kierowana przez samego ideologa nazizmu Alfreda Rosenberga. Niektóre z nich jako własność III Rzeszy trafić miały do muzeum w Linzu, a jednym z cenniejszych nabytków organizacji był Astronom Jana Vermeera, skonfiskowany jako część znakomitej kolekcji Rothschilda ${ }^{8}$. O uprawomocnienie podobnych działań dbały liczne dekrety legalizujące konfiskatę własności „W imię dobra publicznego", a zarząd nad skonfiskowanymi dobrami spra-

${ }^{4}$ J. Świeczyński, dz. cyt., s. 68-69.

${ }^{5}$ S. Lorentz, W muzeum i gdzie indziej, [w:] Walka o dobra kultury. Warszawa 1939-1945, t. I, red. S. Lorentz, Warszawa 1970, s. 24.

${ }^{6}$ Nie istnieją przy tym pełne sprawozdania obrazujące całościowo ich skalę. Dysponujemy jedynie fragmentarycznymi spisami utraconych dóbr kultury. Zniszczenia i grabieże dotknęły również nigdy nieinwentaryzowane kolekcje prywatne czy zbiory należące do organizacji społecznych i kościelnych. S. Lorentz, Wstęp, [w:] Walka o dobra kultury..., s. 7. W sentencji wyroku Międzynarodowego Trybunału Wojskowego czytamy, że w okresie od marca 1941 r. do lipca 1944 do Rzeszy przewieziono 29 załadunków, w skład których wchodziło 137 wagonów towarowych przewożących 4174 skrzynie z dziełami sztuki. Patrz: Trial of the Major War Criminals Before the International Military Tribunal, Nuremberg, 14 November 1945 - 1 October 1946, s. 241242.

${ }^{7}$ A. Łuczak, Instytucje i urzędy III Rzeszy dokonujące grabieży dóbr kultury na okupowanych ziemiach polskich w latach 1939-1945, [w:] Letnia szkota historii najnowszej, t. I, Referaty, red. M. Bielak, Ł. Kamiński, Warszawa 2007, s. 16.

${ }^{8}$ F. Wynne, To ja byłem Vermeerem. Narodziny i upadek największego fałszerza XX wieku, przekł. E. Pankiewicz, Poznań 2018, s. 182. 
wowały specjalnie $\mathrm{w}$ tym celu powołane urzędy powiernicze, $\mathrm{w}$ tym - w odniesieniu do majątku polskiego - Główny Urząd Powierniczy Wschód9

Nazistowska ideologia wyższości ras wywierała przy tym bezpośredni wpływ na sposób traktowania dóbr kultury. W Europie Zachodniej, uważanej za bardziej cywilizowaną od Wschodu, masowo dokonywano ich grabieży. Na Wschodzie, zgodnie z tezą o jego cywilizacyjnej niższości, częściej dochodziło do aktów dewastacji. W Polsce zastosowanie znalazł „system pośredni", zgodnie z którym to, co rodzime, niszczono, wszelkie zaś przejawy zachodnich wpływów grabiono ${ }^{10}$.

Wdrażanie założeń ideologii do systemów administrowania kulturą wyrażało się również w arbitralnych osądach co do tego, co można nazywać sztuką. Warto przypomnieć, że to $\mathrm{w}$ nazistowskich Niemczech narodziło się pojęcie „sztuki zwyrodniałej”, odnoszone do pogardzanych wówczas dzieł współczesnych, dalece niezgodnych z nazistowskimi ideałami. Reżimowa koncepcja tego, co jest, a co nie jest sztuką, wsparta była systemem sankcji grożących niepopularnym artystom. Zdecydowanie najdotkliwsze było wśród nich Malverbot - pozbawienie prawa malowania, konsekwentnie egzekwowane przez gestapo w drodze błyskawicznych inspekcji ${ }^{11}$. Akcja „oczyszczania sztuki" przetoczyła się przez wszystkie niemalże niemieckie muzea, $w$ tym berlińską Nationalgalerie, a jej wynikiem była konfiskata niemal szesnastu tysięcy dzieł $^{12}$. Ich los bywał różny. W najlepszym wypadku trafiały na licytacje i służyły pozyskiwaniu cennych dla III Rzeszy środków finansowych. Inne, co bardziej „obraźliwe” okazy, ukrywano w magazynach, w tym w największej przechowalni dzieł „zdegenerowanych” przy Copernicusstrasse. Wiele z nich nie uniknęło zniszczenia - według szacunków L.H. Nicholasa, 20 marca 1939 r. na dziedzińcu głównej siedziby berlińskiej straży pożarnej spalono aż 4829 eksponató $w^{13}$. Narodowosocjalistyczna Kulturpolitik oznaczała w praktyce, że bezpieczeństwo dóbr kultury zależało bezpośrednio od preferencji, upodobań i wątpliwych kryteriów estetycznych uznawanych przez Hitlera i liczne grono wykonawców jego woli, zorganizowane w Izbę Kultury Rzeszy.

Warto odnotować, że problemu niszczenia dóbr kultury nie sposób rozpatrywać w oderwaniu od jego aspektu psychologicznego. Istnieją bowiem

${ }^{9}$ M. Sikora, Zasady i praktyka przejęcia majątku polskiego przez III Rzeszę, ze szczególnym uwzględnieniem sektora rolnego oraz mieszkaniowego, na przykładzie prowincji śląskiej (górnośląskiej) w latach 1939-1944, „Pamięć i Sprawiedliwość” 2008, t. 7, nr 2(13), s. 45.

${ }^{10}$ J. Świeczyński, dz. cyt., s. 70.

${ }^{11}$ R. Grunberger, Historia społeczna Trzeciej Rzeszy, t. II, przekł. W. Kalinowski, Warszawa 1987, s. 331.

${ }^{12}$ L.H. Nicholas, Grabież Europy. Losy dzieł sztuki w Trzeciej Rzeszy i podczas II wojny światowej, przekł. B. Sławomirska, Poznań 2016, s. 41. Co ciekawe, czystkę w świecie sztuki sankcjonowano prawnie i już w czerwcu 1938 r. przyjęto ustawę zwalniającą rząd z wypłacania jakichkolwiek rekompensat za skonfiskowane eksponaty. Tamże, s. 42.

${ }^{13}$ L.H. Nicholas, dz. cyt., s. 45. 
obiekty w tradycji i symbolice kraju oraz świadomości zamieszkującej go ludności na tyle ważne, że ich utracenie może się przyczynić do wykorzenienia narodowej pamięci, odciskając piętno na szeroko pojętej tożsamości kulturowej narodu. Jako "dokumentacja niepodległego bytu narodu"14 mogą wręcz stanowić symboliczny przejaw historycznej legitymizacji do sprawowania władzy na określonym terytorium ${ }^{15}$. Powyższe znaczenie dóbr kultury „doceniali” zawsze ci, którym zależało na zdławieniu poczucia narodowej odrębności. Taktyka niszczenia wszelkich materialnych przejawów bytności eksterminowanego narodu była regułą w państwach totalitarnych. Podobny zamysł charakteryzował działania niemieckiego okupanta, co dobrze oddają słowa niemieckiego ministra propagandy Josepha Goebbelsa - „odbierzcie narodowi jego kulturę, a przestanie istnieć jako naród"16.

Zdarzało się, że dewastacja dorobku kulturowego stanowiła zwiastun przyszłych prześladowań (prawidłowość tę doskonale oddaje słynny cytat Henricha Heine' go, zgodnie z którym „gdy zaczynamy palić książki, skończymy, paląc ludzi"17) lub wieńczyła dzieło wyniszczania narodu. Prawidłowość tę, w odniesieniu do Polski, potwierdzono w "tezach ogólnych w sprawie rewindykacji i odszkodowań z zakresu kultury i sztuki" - broszurze wydanej w 1945 r. przez Wydział Rewindykacji i Odszkodowań przy Naczelnej Dyrekcji Muzeów i Ochrony Zabytków. W jej fragmencie czytamy: „Niemcy nie mierzyli tylko w kilka pokoleń, ale w sam rdzeń historyczny narodu. Tym tylko wytłumaczyć można doszczętne zniszczenie Zamku Królewskiego w Warszawie, który był symbolem państwowości polskiej. Do tej samej kategorii zniszczeń zaliczyć trzeba spalenie po Powstaniu w r. 1944 wszystkich warszawskich archiwów i wszystkich starych druków polskich z bibliotek warszawskich, wysadzenie w powietrze prawie wszystkich pomników stolicy, burzenie zabytków architektury na terenie całego kraju"18.

W okresie powojennym zajęto się odbudową znacznej części zniszczonych obiektów, częstokroć wbrew ogólnie przyjętym zasadom rekonstrukcji i z narażeniem na zarzut fałszerstwa naukowego ${ }^{19}$. Najlepszy przykład sta-

${ }^{14}$ Określenie S. Żaryna, Dlaczego chronimy zabytki, Warszawa 1966, s. 73.

${ }^{15}$ A. Jakubowski, The Human Dimension of State Succession to Cultural Property: The Balkan Lesson, [w:] Cultural Heritage, Cultural Rights, Cultural Diversity: New Developments in International Law, red. S. Borelli, F. Lenzerini, Boston-Leiden 2012, s. 372.

${ }^{16}$ J. Pruszyński, Dziedzictwo kultury - europejskie, narodowe czy własne? , „Ochrona Zabytków” 1999, nr 4, s. 406.

${ }_{17}$ B. Maciejewska, Dlaczego ludzie co jakiś czas pala ksiażki?Jedni, by bronić narodu, inni - dobrych obyczajów, https:/ / wroclaw.wyborcza.pl/wroclaw/7,35771,24768621,dlaczego-pali-sie-ksiazki-na-stosach.html (dostęp: 12 czerwca 2020 r.).

18 S. Lorentz, W muzeum..., s. 24-25

${ }^{19}$ Doktryna konserwatorska została po raz pierwszy skodyfikowana w tzw. Karcie Ateńskiej z 1931 r., która podkreślała priorytet zachowania autentyczności zabytków. Tezy te podtrzymała Karta wenecka z 1964 r., wytyczająca kierunki w zakresie ochrony i konserwacji za- 
nowi tutaj spontaniczna akcja odbudowy Warszawy. Warto jednak odnotować, iż mimo że została on przeprowadzona w znacznym stopniu wbrew naukowym poglądom, to docenił ją Komitet Światowego Dziedzictwa UNESCO i 2 września 1980 r. Stare Miasto w Warszawie wpisano na Listę UNESCO ${ }^{20}$. Autorem nowych, dopasowanych do okoliczności wytycznych dla prac konserwatorskich był Jan Zachwatowicz - Konserwator Generalny w latach 1945$1957^{21}$. Rewizji zasad konserwatorskich towarzyszyło przekonanie, że „poczucie odpowiedzialności wobec przyszłych pokoleń domaga się odbudowy tego co nam zniszczono, odbudowy pełnej, świadomej tragizmu popełnianego fałszu historycznego" 22 .

Następstwem konfliktu było również wypracowanie metod reparacyjnych, służących powetowaniu strat kulturalnych. Szczególnie bogaty był przy tym dorobek polskich ośrodków, które można uznać za przodujące $\mathrm{w}$ dziedzinie przygotowań mających na celu przeprowadzenie skutecznej akcji reparacyjnej szkód kulturalnych po zakończeniu II wojny światowej. Niestety, jak powszechnie wiadomo, wypracowane przez nie postulaty nie zostały $\mathrm{w}$ pełnym zakresie zrealizowane.

Wśród przedstawicieli polskiej doktryny jednoznacznie dominował pogląd, który najlepiej oddaje maksyma - „za straty w mieniu kulturalnym mienie kulturalne". O powszechnym uznaniu prymatu restytucji zastępczej najlepiej świadczą postulaty formułowane $w$ tym względzie $w$ kręgach opiniotwórczych (wśród konserwatorów zabytków, historyków sztuki oraz in-

bytków architektury. Na jej gruncie konserwacja zabytków zakłada obowiązek ciągłości ich należytego utrzymania (art. 4.), restauracja zaś jest zabiegiem, który ma na celu zachowanie i ujawnienie estetycznej i historycznej wartości zabytku, polegającym na poszanowaniu dawnej substancji i elementów stanowiących autentyczne dokumenty przeszłości i jako taki powinien mieć wyłącznie wyjątkowy charakter (art. 9.).

${ }^{20}$ W uzasadnieniu tej decyzji czytamy: „W sierpniu 1944, w czasie Powstania Warszawskiego, przeszło 85\% zabudowy Starego Miasta zostało zniszczone przez oddziały hitlerowskie. Po wojnie, z woli społeczeństwa, podjęto trwające pięć lat dzieło odbudowy, pieczołowicie restaurując kościoły, pałace oraz Rynek Starego Miasta. Jest to wyjątkowy przykład niemal całkowitej odbudowy zabytków pochodzących z nieprzerwanego ciągu historycznego, od XIII do XX wieku". Patrz: UNESCO. Polskie obiekty na Liście Światowego Dziedzictwa, https://www. unesco.pl/kultura/dziedzictwo-kulturowe/swiatowe-dziedzictwo/polskie-obiekty/ (dostęp: 12 czerwca 2020 r.).

${ }^{21}$ K. Piwocki, Uwagi o odbudowie zabytków, „Biuletyn Historii Sztuki i Kultury” 1946, z. 1-2, s. 53 .

22 J. Zachwatowicz, Program i zasady konserwacji zabytków, „Biuletyn Historii Sztuki i Kultury” 1946, z. 1-2, s. 52. Podobnie K. Piwocki źródeł przemiany poglądów na problem odbudowy zabytku upatrywał $w$ przyczynach emocjonalnych (przywiązanie do dawnych obiektów, odbudowa jako zadośćuczynienie poczuciu sprawiedliwości wobec krzywdy zadanej nam przez wroga), socjalnych (problem przydatności, społecznej użyteczności, „,̇̇yciowej treści” i funkcji odbudowywanego zabytku) i artystycznych (problem uwzględnienia miejsca dawnych budowli monumentalnych w nowych planach urbanistycznych). Patrz: K. Piwocki, dz. cyt., z. 1-2, s. 54-55. 
telektualistów) ${ }^{23}$. Dla przykładu S. Lorentz podkreślał, że „utrata mienia kulturalnego odszkodowana być może tylko $w$ tych samych wartościach, a że mienie kulturalne niemieckie, pochodzące z Polski, lub z Polską zespolone może zadośćuczynić tylko w niewielkim wymiarze, wyrównanie nastąpić powinno w przechowywanym w Niemczech dorobku kulturalnym całej ludzkości. [...] Nie będziemy zabiegać o to, co jest wytworem niemieckiej twórczości - niech nadal sprawują opiekę nad dziełami niemieckiego malarstwa, rzeźby, przemysłu artystycznego. Ale żądać będziemy, by z powszechnego dorobku artystycznego i kulturalnego, stanowiącego dziś własność niemiecką wydzielono pod naszą opiekę taką część, która zadośćuczyniałaby stratom poniesionym $\mathrm{w}$ czasie obecnej wojny" ${ }^{24}$. Ten sam autor wysuwał również śmiałą tezę podzielenia wytworów kultury europejskiej, znajdujących się na ziemiach niemieckich, między państwa poszkodowane przez Niemcy w dziedzinie kultury. Potrzebę tę motywował oczywistymi zaniedbaniami rządu niemieckiego w kwestii obchodzenia się z dobrami kultury o wyjątkowej powszechnej wartości: „Gdy rozważamy rozmiary strat w dziedzinie kultury, poniesionych przez nas i naszych sprzymierzeńców, i uzmysłowimy sobie, jak świadomie i wyrafinowanie, przeprowadzali Niemcy akcje niszczenia cudzego dorobku kulturalnego, nabieramy wątpliwości, czy w ogólne są oni godni dalszego sprawowania opieki nad dobrem kulturalnym, nie przez nich stworzonym, czy należy pozostawić ich pieczy zabytki kultury powszechnej, nieniemieckiej znajdujące się na niemieckich terytoriach! Wątpliwości takie wydają się uzasadnione, bo chyba mamy moralne podstawy odmówienia prawa stróżowania nad dobrem całej ludzkości temu, kto nie uszanował dóbr kulturalnych innych narodów. Nie wysuwamy takiej tezy tylko po to, by stało się zadość sprawiedliwości dziejowej, by zbrodnie w dziedzinie kultury zostały ukarane, lecz po to, by w niezbrukane ręce przeszła opieka nad najszlachetniejszymi, najświetniejszymi przejawami ludzkiego ducha" ${ }^{25}$.

Koncepcja restytucji zastępczej znalazła uznanie państw zachodnioeuropejskich. Szczególne dokonania w tym względzie przypisać należy powołanej z końcem 1942 r. Konferencji Alianckich Ministrów Oświaty (Conference of Allied Ministers of Education), będącej stałym organem konsultacyjnym Narodów Zjednoczonych utworzonym w celu instytucjonalizacji współpracy w zakresie powojennej odbudowy kulturalnej i oświatowej państw europejskich. Zakresem jej działalności objęto również zagadnienia restytucji oraz

${ }^{23}$ Patrz: W. Tatarkiewicz, Etyczne podstawy rewindykacji i odszkodowań, „Prace i Materiały Wydziału Rewindykacji i Odszkodowań Ministerstwa Kultury i Sztuki" 1945, nr 3, s. 22; W. Tomkiewicz, W sprawie restytucji polskiego dorobku w dziedzinie kultury artystycznej, „Przegląd Historyczny" 1946, t. XXXVI, s. 61.

${ }^{24}$ S. Lorentz, O zadośćuczynienie, „Nowa Epoka” 1945, nr 2, s. 2 i nast. (przedruk w: W. Kowalski, Likwidacja skutków II wojny światowej w dziedzinie kultury, Warszawa 1994, s. 135-136).

${ }^{25}$ Tamże. 
odszkodowań kulturalnych, powierzone od 1944 r. specjalnej Komisji ds. Ochrony i Restytucji Dóbr Kultury (Commission for Protection and Restitution of Cultural Material), zwanej - od nazwiska jej przewodniczącego - Komisją Vauchera ${ }^{26}$. Najdonioślejszym, z punktu widzenia rozpatrywanej tematyki, dokonaniem Konferencji był Program restytucji obiektów sztuki, książek i archiwów, w którym opracowano organizacyjne formy rewindykacji dóbr kultury ${ }^{27}$. Dokument określał zasady działania wyspecjalizowanej Komisji, do której kompetencji należeć miało rozpatrywanie roszczeń o przywrócenie zagrabionych, zniszczonych lub uszkodzonych dóbr kultury, które znajdowały się na europejskich terytoriach Narodów Zjednoczonych 1 września 1939 r. W przypadku zniszczeń lub uszkodzeń mienia kulturalnego $\mathrm{w}$ grę wchodzić miała wyłącznie restytucja zastępcza lub zaspokojenie roszczeń z zasobów artystycznych państw „osi”. Jak odnotowuje W. Kowalski: „Komisja winna była mieć stale na uwadze, że nie jest Komisją reparacyjną, a więc nie jest jej celem ustalanie odszkodowań pieniężnych. Wyceny dokonywane być miały przeto możliwie jak najrzadziej. Nigdy przy tym nie należało ich dokonywać w oparciu o kryteria komercyjne. Zasadą jaką należało przyjmować w takich przypadkach było ustalanie wycen tylko wtedy, kiedy zachodziłaby potrzeba przeprowadzenia pewnych prac restauratorskich. W najzupełniej wyjątkowych okolicznościach można było dokonywać wyceny straty bez przekazywania ekwiwalentu" 28 .

W zakresie prawodawstwa państwa świadome, że następstwem II wojny światowej oraz postępującego rozwoju techniki wojennej były ogromne zniszczenia dóbr kultury, przystąpiły do opracowania konwencji, która w zamyśle twórców miała traktować te zagadnienia jako problem suigeneris, wymagający odrębnej regulacji ${ }^{29}$. Prace nad przygotowaniem dokumentu trwały w ramach UNESCO od 1950 do $1954 \mathrm{r}$. W ich trakcie podnoszono częstokroć postulat stworzenia instrumentu odpowiadającego kształtem rozwiązaniom konwencji genewskich z 1949 r., dotyczących ochrony ofiar wojny. Analogie $\mathrm{w}$ zakresie ich celów dały asumpt do przyjęcia nieoficjalnej nazwy projektowanego dokumentu - mówiono o „Karcie Czerwonego Krzyża dla dziedzictwa kulturowego"30.

Akt końcowy konferencji międzynarodowej w sprawie ochrony dóbr kultury w razie konfliktu zbrojnego, podpisany w 1954 r. w Hadze, poza konwencją $\mathrm{w}$ całości poświęconą tematyce ochrony dóbr kultury w razie konfliktu zbrojnego, obejmuje również regulamin wykonawczy oraz protokół.

${ }^{26}$ W. Kowalski, dz. cyt., s. 53-54.

27 S. Nahlik, Grabież dzieł sztuki. Rodowód zbrodni międzynarodowej, Wrocław 1958, s. 286-287.

Szerzej na ten temat patrz również: W. Kowalski, dz. cyt., s. 60 i n.

${ }^{28}$ W. Kowalski, dz. cyt., s. 64.

${ }^{29}$ S. Nahlik, dz. cyt., s. 381-383.

${ }^{30}$ D. Drewniacki, dz. cyt., s. 46. 
Konwencja stanowiła pierwszy wymierny przejaw intensyfikacji współpracy międzynarodowej, jaka po II wojnie światowej nastąpiła w obszarze ochrony dóbr kultury. W rozumieniu dokumentu ochrona dóbr kultury obejmuje opiekę nad nimi oraz ich poszanowanie. Reprezentują one odpowiednio pozytywny oraz negatywny wymiar ochrony, zobowiązując do podjęcia określonych kroków lub powstrzymania się od pewnych działań. W ramach opieki państwa zobowiązane są do przedsięwzięcia już w czasie pokoju szeregu działań mających uchronić położone na ich terytorium dobra kultury przed następstwami konfliktu zbrojnego. Pozostawiono im przy tym swobodę co do wyboru środków, jakie powinny w tym celu podjąć ${ }^{31}$. Co ciekawe, dopiero II protokół do konwencji z 1999 r. wyszczególnia środki przygotowawcze, jakie powinny zostać implementowane w czasie pokoju dla opieki nad dobrami kulturalnymi przed dającymi się przewidzieć skutkami konfliktu zbrojnego $^{32}$. Obejmują one: przygotowanie spisów inwentarza, planowanie środków

${ }^{31}$ Na gruncie polskiego ustawodawstwa postanowienia konwencji haskiej dotyczące problemu opieki znalazły odzwierciedlenie w rozporządzeniu ministra kultury w sprawie organizacji i sposobu ochrony zabytków na wypadek konfliktu zbrojnego i sytuacji kryzysowych z 25 sierpnia 2004 r. (Dz. U. 2004, nr 212, poz. 2153). Na jego gruncie „ochrona zabytków, na wypadek konfliktu zbrojnego i sytuacji kryzysowych, polega na planowaniu, przygotowaniu i realizacji przedsięwzięć zapobiegawczych, dokumentacyjnych, zabezpieczających, ratowniczych i konserwatorskich, mających na celu ich uratowanie przed zniszczeniem, uszkodzeniem lub zaginięciem. Przedsięwzięcia te realizowane są poprzez: zapobieganie i prowadzenie prac przygotowawczych - w czasie poprzedzającym wystąpienie konfliktu zbrojnego lub sytuacji kryzysowej (prace przygotowawcze obejmują w szczególności: opracowanie planów ochrony zabytków na wypadek konfliktu zbrojnego i sytuacji kryzysowych oraz ich aktualizację; kontrolę i doskonalenie stanu technicznego zabytków; instalowanie i utrzymywanie w sprawności urządzeń i systemów zabezpieczenia zabytków, w tym sygnalizacji wykrywania i alarmowania; wykonywanie ewidencji i dokumentacji zabytków podlegających ochronie; projektowanie i wykonywanie inżynieryjno-technicznych prac zabezpieczających przy zabytkach); podwyższenie gotowości - wprowadzanej w okresie narastania bezpośredniego zagrożenia przez właściwe organy kierowania kryzysowego (obejmuje ono następujące działania: demontaż i ukrycie najcenniejszych detali architektonicznych i elementów wyposażenia; przygotowanie i rozmieszczenie znaków rozpoznawczych; zgromadzenie i utrzymywanie w gotowości urządzeń, sprzętu, narzędzi, opakowań, materiałów niezbędnych do wykonania prac zabezpieczających i działań ratowniczych; zorganizowanie systemu monitorowania zagrożeń, alarmowania i powiadamiania; wyznaczenie i przygotowanie zespołów ludzkich do prac zabezpieczających i działań ochronnych; zorganizowanie współdziałania właścicieli, zarządców i użytkowników zabytków, organów administracji publicznej, specjalistycznych służb, jednostek i instytucji, Sił Zbrojnych Rzeczypospolitej Polskiej oraz wolontariatu); reagowanie - w czasie wystąpienia i trwania konfliktu zbrojnego lub sytuacji kryzysowej; zabezpieczenie i dokumentowanie - po ustąpieniu konfliktu zbrojnego lub sytuacji kryzysowej".

32 Drugi protokół do konwencji o ochronie dóbr kulturalnych w razie konfliktu zbrojnego, podpisanej w Hadze 14 maja 1954 r., Haga, 26 marca 1999 r. (Dz.U. 2012, poz. 248). Szerzej na temat dokumentu patrz: H. Schreiber, Drugi Protokót sporządzony w Hadze dnia 26 marca 1999 r. do Konwencji o ochronie dóbr kulturalnych w razie konfliktu zbrojnego, podpisanej w Hadze dnia 14 maja 1954 r., [w:] Konwencje UNESCO w dziedzinie kultury. Komentarz, red. K. Zalasińska, Warszawa 
doraźnych w celu ochrony przed ogniem lub strukturalnym zniszczeniem, przygotowanie do usunięcia ruchomych dóbr kulturalnych lub zabezpieczenie odpowiedniej opieki na miejscu dla takich dóbr oraz wyznaczenie kompetentnych władz odpowiedzialnych za opiekę nad dobrami kulturalnymi.

Poszanowanie dóbr kultury, jako drugi człon ich ochrony, odnosi się do dóbr kultury położonych zarówno na własnym terytorium państwa, jak i terytorium innych umawiających się stron. $W$ jego ramach państwa zobowiązane są do powstrzymywania się od wszelkich aktów nieprzyjacielskich oraz od używania dóbr kultury, a także ich otoczenia i środków przeznaczonych do ich ochrony do celów, które mogłyby je narażać na zniszczenie lub uszkodzenie. Poszanowanie dóbr kultury polega również na zakazie kradzieży, rabunku, bezprawnego przywłaszczania oraz wszelkich aktów wandalizmu. Wyłączone jest również stosowanie rekwizycji wobec ruchomych dóbr kultury położonych na terytorium którejkolwiek ze stron. Dobra kultury nie mogą nadto stanowić przedmiotu represaliów.

Konwencja przewiduje dwa zakresy działań ochronnych - ogólny i specjalny, przy czym ten drugi przysługuje wyłącznie dobrom „o bardzo wielkim znaczeniu”, spełniającym warunek właściwego usytuowania (wymóg oddalenia od wielkich ośrodków przemysłowych oraz od wszelkich ważnych obiektów wojskowych stanowiących punkty wrażliwe) i nieużytkowanym do celów wojskowych. Zgodnie z brzmieniem art. 9. konwencji skutkiem przyznania dobrom kultury ochrony specjalnej jest ich „nietykalność", oznaczająca zobowiązanie państw do powstrzymania się od wszelkich aktów nieprzyjacielskich skierowanych przeciwko tym dobrom oraz od wszelkiego użytkowania tychże dóbr lub ich otoczenia do celów wojskowych.

Do wymienionych rodzajów ochrony II protokół z 1999 r. dodał trzeci zakres, jakim jest ochrona wzmocniona. Jej przyznanie jest możliwe w przypadku spełnienia przez dobro kultury trzech warunków: a) jest ono dziedzictwem kulturalnym o największym znaczeniu dla ludzkości; b) jest chronione na mocy odpowiednich krajowych środków prawnych i administracyjnych uznających jego wyjątkową wartość kulturalną i historyczną i zapewniających mu ochronę $\mathrm{w}$ najwyższym stopniu; c) nie jest wykorzystywane do celów wojskowych lub dla osłony miejsc wojskowych i strona, która sprawuje władzę nad tym dobrem kulturalnym, złożyła deklarację potwierdzającą, że nie będzie ono $w$ taki sposób wykorzystane. Podobnie jak w przypadku ochrony specjalnej, skutkiem objęcia dóbr ochroną wzmocnioną jest zapewnienie im przywileju nietykalności. Decyzję o przyznaniu ochrony wzmocnionej podejmuje komitet ochrony dóbr kulturalnych w razie konfliktu zbrojnego, utworzony na podstawie art. 24. protokołu.

2014; W. Białek, A. Białek-Guillemette, II Protokół do konwencji haskiej z 1954 r. o ochronie dóbr kulturalnych, "Cenne, Bezcenne, Utracone” 2000, nr 5. 
Stosowne postanowienia konwencji dotyczą również terytoriów okupowanych. Na mocy jej art. 5. państwo, które okupuje w całości lub w części określone terytorium, powinno popierać wysiłki właściwych władz narodowych tegoż, których celem jest zapewnienie dobrom kulturalnym opieki i ich zachowanie. Ponadto, gdy w celu zachowania dóbr kulturalnych położonych na terytorium okupowanym konieczne jest działanie natychmiastowe, a właściwe władze narodowe nie mogą go podjąć, władze okupacyjne zobowiązane są do przedsięwzięcia koniecznych środków zachowawczych w ścisłej współpracy z władzami okupowanego państwa.

Należy odnotować, że dyrektywy dotyczące poszanowania dóbr kulturalnych w czasie wojny mogą zostać uchylone, gdy wymaga tego konieczność wojskowa. Burzliwe dyskusje nad dopuszczalnością tej klauzuli od zawsze ogniskowały się wokół dwóch stanowisk, będących wyrazem antynomii między skutecznością a humanitaryzmem. Z jednej strony dostrzega się potrzebę jej uwzględnienia $\mathrm{z}$ uwagi na realia wojen, $\mathrm{z}$ drugiej - podnosi się konieczność eliminowania jakichkolwiek usprawiedliwień aktów wandalizmu, zgodnie z przekonaniem, że interes dóbr kultury niesłusznie ustępuje za jej przyczyną wojennej racji stanu ${ }^{33}$. Kompromisem miało być możliwie jak największe limitowanie dopuszczalności jej stosowania. W przypadku ochrony ogólnej mowa o kategorycznej konieczności wojskowej ${ }^{34}$, a uściślenie pojęcia oraz zaostrzenie warunków stosowania klauzuli nastąpiło w II protokole dodatkowym do konwencji haskiej. Na mocy jego art. 6. stwierdzono po pierwsze, że w celu zapewnienia poszanowania dóbr kulturalnych uchylenie na podstawie kategorycznej konieczności wojskowej może być powołane $\mathrm{w}$ celu skierowania ataku nieprzyjacielskiego wobec dobra kulturalnego jedynie wtedy i na tak długo, jak to dobro kulturalne poprzez swoje przeznaczenie zostało przekształcone w cel wojskowy. Po drugie, wykorzystanie dóbr kulturalnych dla celów, które prawdopodobnie narażą je na zniszczenie lub uszkodzeniejest możliwe jedynie wtedy i na tak długo, dopóki nie istnieje możliwość wyboru pomiędzy takim wykorzystaniem dóbr kulturalnych a inną praktyczną metodą uzyskania podobnej korzyści wojskowej. Po trzecie, decyzja o przywołaniu kategorycznej konieczności wojskowej jest podej-

${ }^{33}$ K. Lankosz, Ochrona dóbr kultury, konflikty zbrojne i prawo międzynarodowe, [w:] Prawo - władza - społeczeństwo - polityka. Księga jubileuszowa profesora Krzysztofa Pałeckiego, red. M. Borucka-Arctowa i in., Toruń 2006, s. 230.

${ }^{34} \mathrm{~W}$ odniesieniu do ochrony specjalnej przewidziano natomiast, że przywilej nietykalności może być cofnięty jedynie w wypadkach nie dającej się uniknąć konieczności wojskowej i jedynie na czas jej trwania. Stwierdzić, że konieczność taka zachodzi, może przy tym jedynie dowódca jednostki odpowiadającej dywizji bądź wyższej. Tytułem uzupełnienia wskazano, że jeżeli pozwalają na to okoliczności, decyzja cofnięcia przywileju nietykalności powinna być zakomunikowana odpowiednio wcześnie stronie przeciwnej oraz Komisarzowi Generalnemu Dóbr Kulturalnych przewidzianemu w regulaminie wykonawczym. 
mowana jedynie przez oficera dowodzącego jednostką odpowiadającą batalionowi lub wyższą albo siłą mniejszą pod względem rozmiarów w sytuacji, gdy okoliczności nie pozwalają inaczej. Wreszcie po czwarte, w razie ataku, jeżeli tylko pozwalają na to okoliczności, należy ostrzec stronę przeciwną.

W ramach ogólnego katalogu zobowiązań państw wynikających z konwencji haskiej z 1954 r. wyróżnić możemy cztery ich kategorie:

1) zobowiązania zmierzające do ochrony materialnej substancji dóbr kultury;

2) zobowiązania natury wychowawczej związane z budowaniem poczucia szacunku dla dóbr kultury;

3) zobowiązania natury popularyzacyjnej związane z rozpowszechnianiem tekstu konwencji;

4) zobowiązania dotyczące dostosowania krajowych systemów prawa karnego poprzez wprowadzenie sankcji za naruszenia międzynarodowych zobowiązań z zakresu ochrony dóbr kultury.

Krytycznie ocenić należy fakt, że rozbudowanym zobowiązaniom państw nie towarzyszy skuteczny mechanizm służący ich realizacji ${ }^{35}$. Deficyt w zakresie mechanizmów kontrolnych przejawia się w szczególności w braku stosownych organów monitorujących przestrzeganie konwencji. Kwestia konwencyjnej instytucjonalizacji ochrony była przedmiotem prac komitetu ekspertów trwających od 21 lipca do 14 sierpnia 1952 r., poprzedzających przyjęcie konwencji UNESCO z $1954 \mathrm{r} .{ }^{36}$ Pod rozwagę brano trzy możliwe modele kontroli stosowania konwencji. Pierwszy z nich, związany z ustanowieniem specjalnej organizacji międzynarodowej powołanej do administrowania konwencją, odrzucono, niestety, ze względu na relatywną zawiłość i wysokie koszty implementacji ${ }^{37}$. Wydaje się, że taki model instytucjonalny, nazywany tradycyjnie modelem autonomicznym, stanowiłby najlepszą gwarancję efektywnej implementacji konwencji. Pozwoliłby on bowiem na szybkie stwierdzenie przypadków naruszeń jej postanowień, a co za tym idzie określenie ram i form ewentualnej odpowiedzialności państwa ${ }^{38}$.

Odrzucono również drugi z proponowanych modeli, zakładający wykorzystanie już istniejących struktur organizacyjnych. Jak można się domyślać, celowi temu najlepiej służyć miała UNESCO. Ostatecznie, przyznane organizacji kompetencje z zakresu udzielania pomocy technicznej w zorganizowaniu ochrony dóbr kultury, nie pozwalają jej jednak traktować jako nadrzęd-

${ }^{35}$ E. Cunliffe, N. Muhesen, M. Lostal, The Destruction of Cultural Property in the Syrian Conflict: Legal Implications and Obligations, "International Journal of Cultural Property" 2016, issue 23, s. 16 .

${ }^{36}$ UNESCO Doc. 7 C/PRG/7.

37 Tamże.

38 Patrz: A. Przyborowska-Klimczak, Ochrona przyrody. Studium prawnomiędzynarodowe, Lublin 2004, s. 287. 
nego organu kontroli. Pewne kompetencje w procesie kontroli implementacji konwencji przyznano organom UNESCO. Na mocy art. 26. konwencji państwa-strony zobowiązane są do przedkładania Dyrektorowi Generalnemu UNESCO raz na cztery lata sprawozdań o środkach powziętych, przygotowanych lub zamierzonych celem wykonania konwencji i jej regulaminu wykonawczego. Niestety, organ ten nie posiada formalnego prawa do zajmowania stanowiska w kwestii realizacji zobowiązań państw.

Ostatni z modeli, który znalazł ostatecznie zastosowanie, przewidywał powołanie tzw. mocarstw opiekuńczych. Im powierzono zadanie świadczenia dobrych usług $w$ przypadkach, gdy między stronami konfliktu powstanie różnica zdań co do stosowania lub interpretacji postanowień konwencji. Zgodnie $\mathrm{z}$ regulaminem wykonawczym $\mathrm{w}$ ramach procesu weryfikacji przestrzegania konwencji delegaci mocarstw opiekunczych mogą stwierdzić naruszenia, zbadać ich okoliczności oraz przedstawić swoje démarche, aby ich zaniechano. Co istotne, model ten, odpowiadający być może realiom ówczesnych stosunków międzynarodowych, niestety, już się zdezaktualizował. Niestosowany właściwe od czasu zakończenia II wojny światowej, współcześnie jest całkowicie nieskuteczny ${ }^{39} \mathrm{i}$ wymaga rewizji.

Implementacji konwencji sprzyjać miała również możliwość zwoływania zebrań przedstawicieli państw-stron, których zadaniem jest badanie zagadnień związanych ze stosowaniem konwencji i jej regulaminu wykonawczego oraz formułowanie na ten temat zaleceń. Ponadto w regulaminie wykonawczym przewidziano funkcję komisarza generalnego ds. dóbr kulturalnych, który zajmuje się wszelkimi sprawami wiążącymi się z wykonywaniem konwencji. Za zgodą strony, przy której pełni on swoje zadania, komisarz może przeprowadzić dochodzenie, a swoje stanowisko przedstawia w démarches oraz sprawozdaniach dotyczących wykonywania konwencji. Powyższe rozwiązanie instytucjonalne stanowić miało kompromis, godzący sprzeczne poglądy co do potrzeby utworzenia stałego ciała, które sprawowałoby kontrolę nad przestrzeganiem konwencji ${ }^{40}$. Wydaje się jednak, że brak stałego, autonomicznego mechanizmu instytucjonalnego stanowi jej główną słabość i może być przyczyną jej niewielkiej skuteczności. Istniejące w ramach mechanizmu instytucjonalnego organy pełnią wyłącznie funkcje doradcze i operacyjne, bez realnej możliwości wpływania na postępowanie państw. Zgodnie z pierwotnym zamysłem twórców konwencji, wyposażenie ich w szerszy zakres kompetencji mogłoby odstraszyć państwa od przystępowania do trakta-

${ }^{39}$ Patrz: Meeting of Experts on the Application and Effectiveness of the Convention for the Protection of Cultural Property in the Event of Armed Conflict,Final Report, Hague 14 May 1954, s. 5.

${ }^{40} \mathrm{H}$. Schreiber, Konwencja o ochronie dóbr kulturalnych $w$ razie konfliktu zbrojnego wraz $z$ Regulaminem wykonawczym do tej Konwencji oraz Protokół o ochronie dóbr kulturalnych w razie konfliktu zbrojnego podpisane w Hadze dnia 14 maja 1954 r., [w:] Konwencje UNESCO w dziedzinie kultury. Komentarz, red. K. Zalasińska, Warszawa 2014, s. 80-81. 
tu. Paradoksalnie więc, ta niedoskonałość konwencji wpłynęła na poszerzenie kręgu jej sygnatariuszy.

Warto zauważyć, że przyjęcie konwencji haskiej z 1954 r. stanowiło jedynie preludium do bardzo prężnej działalności UNESCO na polu ochrony dóbr kultury. Dokument stał się punktem wyjścia dla konstruowania innych aktów prawnych uszczegóławiających zasady postępowania z dziedzictwem kulturalnym. Dowodem na coraz bardziej kompleksowe pojmowanie zagadnienia jego ochrony są: konwencja dotycząca środków zmierzających do zakazu i zapobiegania nielegalnemu przywozowi, wywozowi i przenoszeniu własności dóbr kulturalnych z 17 listopada 1970 r. ${ }^{41}$; konwencja w sprawie ochrony światowego dziedzictwa kulturalnego i naturalnego z 16 listopada 1972 r. ${ }^{42}$; konwencja o ochronie podwodnego dziedzictwa kulturalnego z 2 listopada 2001 r. $^{43}$; konwencja w sprawie ochrony niematerialnego dziedzictwa kulturalnego z 17 października $2003 \mathrm{r}^{44}$

Dokonując analizy wpływu II wojny światowej na kształtowanie się rozwiązań prawnych z zakresu ochrony dóbr kultury, należy zauważyć, że po zakończeniu konfliktu, na skutek wyodrębnienia trzech kategorii zbrodni, w tym zbrodni wojennej, obejmującej swym zakresem bezmyślne burzenie miast lub wsi oraz dokonywanie spustoszeń nieusprawiedliwionych koniecznością wojenną, problematyka ochrony dóbr kultury wpisana została $\mathrm{w}$ ramy wydzielonego reżimu traktatowego, jakim jest międzynarodowe prawo karne. Państwa, przekonane o ponadnarodowej wartości dóbr kultury i kolektywnym interesie $\mathrm{w}$ ich zachowaniu, zaczęły podejmować wysiłki zmierzające do penalizacji czynów przestępczych wymierzonych w dziedzictwo kulturowe. Pierwszą w historii próbą egzekwowania międzynarodowego prawa humanitarnego dotyczącego ochrony dóbr kultury był proces przed Międzynarodowym Trybunałem Wojskowym w Norymberdze (MTW). Jurysdykcja Trybunału w zakresie czynów przestępczych skierowanych przeciwko dobrom kultury (tj. zbrodni wojennych) wynikała $\mathrm{z}$ art. 6 . lit. b Karty Międzynarodowego Trybunału Wojskowego, zgodnie z którym „pogwałcenia takie będą obejmowały, nie ograniczając się jednak do nich: [...] grabież mienia publicznego lub prywatnego, zbyteczne niszczenie miast, miasteczek lub wsi oraz pustoszenie kraju nie usprawiedliwione konieczno-

${ }^{41}$ Konwencja dotycząca środków zmierzających do zakazu i zapobiegania nielegalnemu przywozowi, wywozowi i przenoszeniu własności dóbr kulturalnych, Paryż, 17 listopada $1970 \mathrm{r}$. (Dz. U. 1974, nr 20, poz. 106.)

${ }^{42}$ Konwencja w sprawie ochrony światowego dziedzictwa kulturalnego i naturalnego, Paryż, 16 listopada 1972 r., (Dz. U. 1976, nr 32, poz. 190).

${ }^{43}$ Konwencja ta nie została jak dotąd ratyfikowana przez Polskę.

${ }^{44}$ Konwencja w sprawie ochrony niematerialnego dziedzictwa kulturalnego, Paryż, 17 października 2003 r. (Dz. U. 2011, nr 172, poz. 1018). 
ścią wojskową" ${ }^{45}$. Choć w porównaniu z innymi typami zbrodni Trybunał poświęcał przypadkom grabieży i zniszczeń dóbr kultury stosunkowo niewiele miejsca, to już samo pojawienie się tych czynów w rejestrze win sądzonych zbrodniarzy było zwiastunem pozytywnej zmiany $\mathrm{w}$ tym zakresie. Poza koniecznością przeprowadzenia akcji rewindykacyjnych, mających służyć w możliwie najpełniejszym zakresie zaspokojeniu pretensji poszkodowanych państw, było jasne, że każdy akt barbarzyństwa musi spotkać się z indywidualną odpowiedzialnością jednostki, mimo podnoszonych przez obronę argumentów o wyłącznej odpowiedzialności państwa. Umożliwiło to pociągnięcie do odpowiedzialności m.in. takich zbrodniarzy jak Goering - sądzony za liczne akcje grabieżcze, właściciel prywatnej kolekcji sztuki, czy Rosenberg - odpowiedzialny za grabieże zarówno własności publicznej, jak i prywatnej w okupowanych krajach Europy ${ }^{46}$.

Należy odnotować, że współcześnie egzekwowanie odpowiedzialności jednostek za szkody wyrządzone dobrom kultury jest możliwe na gruncie Statutu Międzynarodowego Trybunału Karnego (MTK), który do zbrodni wojennych zalicza poważne naruszenia praw i zwyczajów prawa międzynarodowego, mających zastosowanie zarówno do konfliktów zbrojnych o charakterze międzynarodowym, jak i tych niemających takiego charakteru, polegające na zamierzonym kierowaniu ataków na budynki przeznaczone na cele religijne, edukacyjne, artystyczne, naukowe lub charytatywne, pomniki historyczne, szpitale oraz miejsca, gdzie gromadzeni są ranni i chorzy, pod warunkiem, że nie są one celami wojskowymi ${ }^{47}$.

Podsumowując, można zauważyć, że system prawnej ochrony dóbr kultury nie ma długiej tradycji. Jego rozkwit przypada dopiero na $X X \mathrm{w}_{\text {., }}$ przy czym to właśnie po zakończeniu II wojny światowej obserwowaliśmy znaczną intensyfikację działań społeczności międzynarodowej na tym polu. Stopniowo dochodziło przy tym do poszerzania kontekstu funkcjonowania przepisów z zakresu ochrony dóbr kultury ${ }^{48}$. Należy odnotować, że niestety, mimo znacznego stopnia rozwoju prawa nie wyeliminowano całkowicie niechlubnego procederu niszczenia dóbr kultury. Konfrontując bogate instrumentarium prawne z liczbą zniszczonych tylko w ostatnim czasie obiektów, można dojść do smutnej konstatacji, że prawo ochrony dóbr kultury nie spełnia swojej funkcji, a potrzeba zachowania dziedzictwa kulturalnego wciąż ustępuje przed wojenną racją stanu. Ogrom zniszczeń towarzyszących kon-

${ }^{45}$ Karta Międzynarodowego Trybunału Wojskowego (Dz. U. 1947, nr 63, poz. 367).

${ }^{46}$ J. Świeczyński, dz. cyt., s. 73.

47 Patrz: art. 8. ust. 2. lit. b(ix) oraz art. 8. ust. 2. lit. e(iv). Rzymski Statut Międzynarodowego Trybunału Karnego (Dz. U. 2003,nr 78, poz. 708).

${ }^{48}$ H. Schreiber, A. Budziszewska, W strone prawa do kultury?, [w:] Ochrona dziedzictwa kultury w konfliktach zbrojnych w świetle prawa międzynarodowego i krajowego. 60 lat Konwencji haskiej i 15 lat jej Protokołu II, red. E. Mikos-Skuza, K. Sałaciński, Warszawa 2015, s. 70. 
fliktowi jugosłowiańskiemu, destrukcja posągów Buddy w Bamianie, agresja islamskich fundamentalistów w Timbuktu czy masowe niszczenie skarbów kultury w Iraku i Syrii dowodzą, że nawet późniejsze, bardziej szczegółowe regulacje nie stanowią $\mathrm{w}$ tym zakresie gwarancji bezpieczeństwa.

\section{Bibliografia}

\section{Źródła drukowane}

Drugi Protokół do Konwencji o ochronie dóbr kulturalnych w razie konfliktu zbrojnego, podpisanej w Hadze dnia 14 maja 1954 r., Haga, 26 marca 1999 r. (Dz. U. 2012, poz. 248).

Karta Międzynarodowego Trybunału Wojskowego (Dz. U. 1947, nr 63, poz. 367).

Konwencja dotycząca środków zmierzających do zakazu i zapobiegania nielegalnemu przywozowi, wywozowi i przenoszeniu własności dóbr kulturalnych, Paryż, 17 listopada 1970 r. (Dz. U. 1974, nr 20, poz. 106).

Konwencja w sprawie ochrony niematerialnego dziedzictwa kulturalnego, Paryż, 17 października 2003 r. (Dz. U. 2011, nr 172, poz. 1018).

Konwencja w sprawie ochrony światowego dziedzictwa kulturalnego i naturalnego, Paryż, 16 listopada 1972 r. (Dz. U. 1976, nr 32, poz. 190).

Meeting of Experts on the Application and Effectiveness of the Convention for the Protection of Cultural Property in the Event of Armed Conflict, Final Report, Hague 14 May 1954.

Rozporządzenie Ministra Kultury w sprawie organizacji i sposobu ochrony zabytków na wypadek konfliktu zbrojnego i sytuacji kryzysowych z dnia 25 sierpnia 2004 r. (Dz. U. 2004, nr 212, poz. 2153).

Rzymski Statut Międzynarodowego Trybunału Karnego (Dz. U. 2003, nr 78, poz. 708).

Trial of the Major War Criminals Before the International Military Tribunal, Nuremberg, 14 November 1945 - 1 October 1946.

UNESCO Doc. 7 C/PRG/7.

\section{Opracowania}

Białek W., Białek-Guillemette A., II Protokót do konwencji haskiej z 1954 r. o ochronie dóbr kulturalnych, "Cenne, Bezcenne, Utracone” 2000, nr 5.

Cunliffe E., Muhesen N., Lostal M., The Destruction of Cultural Property in the Syrian Conflict: Legal Implications and Obligations, „International Journal of Cultural Property” 2016, issue 23.

Drewniacki D., Międzynarodowa ochrona dóbr kultury w razie konfliktów zbrojnych. Materiały i komentarze, Warszawa 2000.

Grunberger R., Historia społeczna Trzeciej Rzeszy, t. II, przekł. W. Kalinowski, Warszawa 1987.

Jakubowski A., The Human Dimension of State Succession to Cultural Property: The Balkan Lesson, [w:] Cultural Heritage, Cultural Rights, Cultural Diversity: New Developments in International Law, red. S. Borelli, F. Lenzerini, Boston-Leiden 2012.

Kowalski W., Likwidacja skutków II wojny światowej w dziedzinie kultury, Warszawa 1994.

Lankosz K., Ochrona dóbr kultury, konflikty zbrojne i prawo międzynarodowe, [w:] Prawo - władza społeczeństwo - polityka. Księga jubileuszowa profesora Krzysztofa Pałeckiego, red. M. Borucka-Arctowa i in., Torun 2006.

Lorentz S., O zadośćuczynienie, „Nowa Epoka” 1945, nr 2.

Lorentz S., W muzeum i gdzie indziej, [w:] Walka o dobra kultury. Warszawa 1939-1945, t. I, red. S. Lorentz, Warszawa 1970.

Lorentz S., Wstęp, [w:] Walka o dobra kultury. Warszawa 1939-1945, t. I, red. S. Lorentz, Warszawa 1970. 
Łuczak A., Instytucje i urzędy III Rzeszy dokonujące grabieży dóbr kultury na okupowanych ziemiach polskich w latach 1939-1945, [w:] Letnia szkoła historii najnowszej, t. I, Referaty, red. M. Bielak, Ł. Kamiński, Warszawa 2007.

Maciejewska B., Dlaczego ludzie co jakiś czas pala ksiażki? Jedni, by bronić narodu, inni - dobrych obyczajów, https://wroclaw.wyborcza.pl/wroclaw/7,35771,24768621,dlaczego-pali-sie-ksiaz ki-na-stosach.html (dostęp: 12 czerwca 2020 r.).

Nahlik S., Grabież dzieł sztuki. Rodowód zbrodni międzynarodowej, Wrocław 1958.

Nicholas L.H., Grabież Europy. Losy dziet sztuki w Trzeciej Rzeszy i podczas II wojny światowej, przekł. B. Sławomirska, Poznań 2016.

Piwocki K., Uwagi o odbudowie zabytków, „Biuletyn Historii Sztuki i Kultury” 1946, z. 1-2.

Pruszyński J., Dziedzictwo kultury - europejskie, narodowe czy własne?, „Ochrona Zabytków” 1999, nr 4.

Przyborowska-Klimczak A., Ochrona przyrody. Studium prawnomiędzynarodowe, Lublin 2004.

Schreiber H., Budziszewska A., W strone prawa do kultury?, [w:] Ochrona dziedzictwa kultury $w$ konfliktach zbrojnych w świetle prawa międzynarodowego i krajowego. 60 lat Konwencji haskiej i 15 lat jej Protokotu II, red. E. Mikos-Skuza, K. Sałaciński, Warszawa 2015.

Schreiber H., Drugi Protokót sporządzony w Hadze dnia 26 marca 1999 r. do Konwencji o ochronie dóbr kulturalnych w razie konfliktu zbrojnego, podpisanej w Hadze dnia 14 maja 1954 r., [w:] Konwencje UNESCO w dziedzinie kultury. Komentarz, red. K. Zalasińska, Warszawa 2014.

Schreiber H., Konwencja o ochronie dóbr kulturalnych w razie konfliktu zbrojnego wraz z Regulaminem wykonawczym do tej Konwencji oraz Protokót o ochronie dóbr kulturalnych w razie konfliktu zbrojnego podpisane w Hadze dnia 14 maja 1954 r., [w:] Konwencje UNESCO w dziedzinie kultury. Komentarz, red. K. Zalasińska, Warszawa 2014.

Sikora M., Zasady i praktyka przejęcia majątku polskiego przez III Rzeszę, ze szczególnym uwzględnieniem sektora rolnego oraz mieszkaniowego, na przykładzie prowincji śląskiej (górnoślaskiej) w latach 1939-1944, „Pamięć i Sprawiedliwość” 2008, t. 7, nr 2(13).

Świeczyński J., Grabieżcy kultury i fatszerze sztuki, Warszawa 1986.

Tatarkiewicz W., Etyczne podstawy rewindykacji i odszkodowan, „Prace i Materiały Wydziału Rewindykacji i Odszkodowań Ministerstwa Kultury i Sztuki" 1945, nr 3.

Tomkiewicz W., W sprawie restytucji polskiego dorobku w dziedzinie kultury artystycznej, „Przegląd Historyczny" 1946, t. XXXVI.

UNESCO. Polskie obiekty na Liście Światowego Dziedzictwa, https://www.unesco.pl/kultu ra/dziedzictwo-kulturowe/swiatowe-dziedzictwo/polskie-obiekty/ (dostęp: 12 czerwca 2020 r.).

Wynne F., To ja byłem Vermeerem. Narodziny i upadek największego fatszerza XX wieku, przekł. E. Pankiewicz, Poznań 2018.

Zachwatowicz J., Program i zasady konserwacji zabytków, „Biuletyn Historii Sztuki i Kultury” 1946, z. 1-2.

Żaryn S., Dlaczego chronimy zabytki, Warszawa 1966. 
Sylwia Stryjkowska

\title{
Wpływ II wojny światowej na poszukiwanie rozwiązań prawnych w zakresie ochrony dóbr kultury
}

\section{Streszczenie}

Artykuł ukazuje zmiany, jakie nastąpiły w systemie prawnej ochrony dóbr kultury po zakończeniu II wojny światowej. Konflikt ten przyczynił się do bezprecedensowych strat w zasobach kulturowych, by następnie stać się punktem wyjścia do prac nad narzędziami prawnej ochrony dziedzictwa kulturalnego. Ukazując proces kształtowania się rozwiązań prawnych w tym zakresie, szczególną uwagę zwrócono na Konwencję w sprawie ochrony dóbr kultury w razie konfliktu zbrojnego podpisaną w 1954 r. w Hadze, która stanowiła pierwszy wymierny przejaw intensyfikacji współpracy międzynarodowej, jaka po II wojnie światowej nastąpiła w obszarze ochrony dóbr kultury.Uwagę poświęcono nadto metodom reparacyjnym służącym powetowaniu doznanych w konflikcie strat kulturalnych.

Słowa kluczowe: II wojna światowa, dobra kultury, ochrona dóbr kultury, prawo międzynarodowe publiczne

Sylwia Stryjkowska

\section{The impact of the Second World War on the process of seeking legal solutions in the field of cultural property protection}

\begin{abstract}
The article demonstrates changes chich occurred in the system of legal protection of cultural property after the Second World War. This conflict caused unprecedented cultural losses, and became the starting point for work on solutions aiming at legal protection of cultural heritage. The importance of the 1954 Hague Convention for the Protection of Cultural Property in the Event of Armed Conflict is particularly highlighted. The convention was the first concrete evidence of intensified international cooperation that occurred after the Second World War in the area of cultural property protection. The article also presents approaches to reparations for cultural losses sustained during the conflict.
\end{abstract}

Keywords: Second World War, cultural property, cultural property protection, international public law 